\title{
LEARNING FROM THE PERIPHERY: BEYOND THE TRANSNATIONAL MODEL
}

\author{
By \\ Ayse Saka-Helmhout \\ School of Management, \\ University of Surrey, \\ Guildford, \\ Surrey GU2 7XH, \\ UK
}

Tel: $+44-1483-689667$

a.saka-helmhout@surrey.ac.uk

Forthcoming in Critical Perspectives on International Business in 2011 


\title{
LEARNING FROM THE PERIPHERY: BEYOND THE TRANSNATIONAL MODEL
}

\begin{abstract}
Purpose-Numerous studies have proliferated on the salient role of the subsidiary in multinational enterprise learning and innovative capability building. However, this role has not been considered outside the structural properties of the transnational or integrated network configuration. This paper aims to highlight the role of agency in learning beyond effective configurations.
\end{abstract}

Design/methodology/approach - The research is based on case studies that systematically compare the ways in which parent company knowledge embedded in a transnational and an international structure is transferred to subsidiaries in the European chemical industry.

Findings-The paper demonstrates that an international structure can also promote higher levels of learning, despite the absence of learning-facilitating structural properties, when subsidiaries' orientation to enact acquired knowledge or their 'effortful accomplishments’ are considered.

Practical implications - The findings point to the significance of agency or adaptation to contexts that require either idiosyncratic or ongoing changes where structural properties of a multinational are not conducive to higher levels of learning. In the absence of these structural properties, employees need to be guided to change their recognisable pattern of interdependent actions.

Originality/value-The learning implications of Bartlett and Ghoshal's MNE structures are fine-tuned with the conceptualization of learning as practice. By adopting an agency-based understanding of learning, we reconcile the two aspects of learning, i.e. 
knowledge transfer and the actor's orientation to acquired knowledge for a more refined understanding of the concept within the MNE context.

Keywords: Organizational learning, social agency, subsidiary entrepreneurship, MNE structure

Paper type: Research paper 


\section{Introduction}

The importance of knowledge transfer and learning has been noted in its link to competitive advantage in the field of strategic management (e.g. Lane and Lubatkin, 1998), and international business (e.g. Kedia and Bhagat, 1988). The growing interest in the determinants of an organization's ability to acquire, assimilate, and exploit knowledge, i.e. an organization’s absorptive capacity (Cohen and Levinthal, 1990), has served to advance our understanding of why some organizations thrive and others struggle when faced with similar environmental conditions. Organization structure has been acknowledged as one of the knowledge processing systems that leads to high absorptive capacity (see Lane and Lubatkin, 1998; Van den Bosch et al., 1999). In the field of international management, the emphasis is on the learning facilitating mechanisms of the 'heterarchy', 'transnational', and 'multifocal' organization structure (Bartlett and Ghoshal, 1989; Hedlund, 1994; Prahalad and Doz, 1981). It is believed that the transnational or the integrated network model provides a valuable perspective on learning, because it reflects the organic evolutionary development of distinctive resources in the subsidiary (Birkinshaw and Hood, 1998: 778). However, this discussion has predominantly focused on the structural properties of multinationals, not recognizing the full significance of agency, or activities of people, that promote learning. The attribution of learning to structural properties has tended to forego actors' orientations to enacting knowledge.

While not discrediting the importance of 'rich and complex communication linkages, work interdependencies, and formal and informal systems' (Bartlett and Ghoshal, 1989: 61) in the transnational structure, we argue here that learning can be promoted from the periphery—in non-networked structures—upon its conceptualization as practice that focuses on the importance of actors as the artful manipulators of the 
constraints and capital afforded by their social positions. This conceptualization builds on the growing interest in absorptive capacity as a dynamic capability embedded in a firm's routines and processes (Zahra and George, 2002), where the implications are that learning may not simply emerge from the gradual development of routines, but be achieved through an orientation to radically change routines. Consequently, we contend that where effective structural properties are not available to promote learning within the multinational enterprise (MNE), actors' orientation to modify routines, or in Zahra and George’s (2002) term 'realized capacity’, gains importance in encouraging higher levels of learning. We illustrate this through a comparison of an international structure with a transnational structure in a systematic case study of two MNEs in the European chemical industry.

Learning is understood here as embedding or encoding acquired knowledge into routines that guide behaviour (Levitt and March, 1988). In alignment with this understanding, we conceptualize learning as having two aspects: knowledge flow (or 'potential capacity') and the actor's orientation to acquired knowledge (or 'realized capacity', Zahra and George, 2002), which can either reinforce or change routines. Contrary to what is commonly purported in the mainstream international business literature (e.g. Vermeulen and Barkema, 2001), we attribute learning to the role of agency in knowledge acquisition rather than assume that learning has taken place upon a multinational's exposure to ideas through a transfer. The social perspective on organisational learning has been widely canvassed outside the international management literature (Brown and Duguid, 1991; Lave, 1993). However, the view of organisational learning in international settings is commonly a structuralist one, where learning refers to a process of transferring discrete best practices (e.g. Macharzina et al., 2001; Uhlenbruck et al., 2003). The context-based investigations into the aspects of the 
social system that shape the learning process in international settings have received less attention (see review of debates by Easterby-Smith et al., 1999). Knowledge transfer is, more often than not, used as a proxy for organisational learning. We believe that conceptualising learning in international settings as knowledge transfer severely limits the role of human agency and projects learning as an isomorphic process that leads to similar patterns of learning across foreign subsidiaries. For learning to be claimed, knowledge upon its transfer must be manifested in changed behaviour. As Zahra and George (2002) argue, exposure to knowledge per se does not guarantee that a firm will have higher levels of absorptive capacity. Knowledge must be enacted for learning to be realized. This involves agency or the ability to remember the past, imagine the future, and respond to present circumstances (Emirbayer and Mische, 1998, see also Elkjaer, 1999). Howard-Grenville (2005) summarizes actors' orientations as i) iteration, that is drawing from past artefacts or habits and experiences, ii) application, that is pragmatically adopting artefacts and expectations to respond to the present situation at hand, and iii) projection, that is imagining or planning new uses of artefacts for the future. Discerning the particular intentions and orientations of actors help distinguish between why routines may change over time or persist.

Learning can occur at the lower or higher level (see Fiol and Lyles, 1985) ${ }^{1}$. Lower-level learning is conceptualized as 'those activities which add to the knowledge base or firm-specific competences or routines of the firm without altering the nature of their activities' (Dodgson, 1993: 383). This type of learning reflects the 'passive model of adaptation' characterized by incremental behaviour that is focused on efforts directed at simple maintenance or elaboration of existing routines for efficiency and effectiveness (Miller et al., 1996; Hendry et al., 1995). In keeping consistent with this understanding, the heavy reliance on the past or the iteration of past habits, as well as 
the pragmatic adaptation of artefacts for efficiency and effectiveness (i.e. application) by actors, can be equated with lower-level learning, for they do not involve any change to the nature of activities. After all, lower-level learning is the result of repetition (Fiol and Lyles, 1985). It helps stabilize existing arrangements.

By contrast, higher-level learning refers more to a cognitive process than repetitive behaviour, requiring in-depth understanding of past actions rather than unreflective action-taking (e.g. Fiol and Lyles, 1985). This type of a learning reflects an 'opportunistic model of adaptation' characterized by the search for, and exploration of, a wide variety of alternative activities and modes of operation (Miller et al., 1996) in which efforts are directed at establishing a new orientation to work (Hendry et al., 1995: 105). Higher-level learning is best described in terms of an actor's orientation towards future aspirations, i.e. projection, that promotes cognitive (not simply behavioural) change.

In the following section, we discuss the relationship between Bartlett and Ghoshal's idealized MNE structures and organizational learning, and question its fundamental assumptions. This is followed, in the third section, by the introduction of methodology and empirical setting. The learning patterns associated with the international and transnational structures across the various subsidiaries are reported in the findings section, and the conditions underlying these associations are presented in the section on discussion. In the final section, we present an overview of the contribution of the analysis to the literatures on MNE structure and learning.

\section{Reconceptualizing learning in its link to MNE structure}

There have been several conceptualizations of the MNE, most notably Bartlett and Ghoshal's (1989) 'transnational'. This model sees the MNE as actively seeking 
advantages originating in the global spread of the firm. First, resources, managerial capabilities and decision making are dispersed throughout the organization rather than centralized. Control is exercised through indirect, implicit means such as socialization rather than formal, direct mechanisms such as bureaucracy (Harzing, 1999). Second, there are horizontal relations among subsidiaries for large flows of products, resources, people and knowledge. Third, coordination and cooperation are highly complex owing to shared decision making across geographies, products and functions (Bartlett and Ghoshal, 1989). These structural properties are seen as promoting learning and facilitating local and central innovations within the MNE. Building on the learning implications of transnationals, efforts have focused on delineating factors such as absorptive capacity and motivational disposition that facilitate and inhibit knowledge transfers within MNEs (e.g. Gupta and Govindarajan, 2000; Szulanski, 1996). This emphasis has diverted attention from the means by which learning is realized in other MNE structures where an interorganizational network of differentiated units is not available for fostering innovation. We argue here that conceptualizing learning as practice where absorptive capacity is perceived as a dynamic capability can encourage higher levels of learning in these structures. This calls for an analysis that captures micro processes of agency in putting acquired knowledge into practice Absorptive capacity as a dynamic capability is understood as knowledge acquisition, assimilation, transformation, and exploitation that influences an organization's ability to create and deploy the knowledge necessary to build other organizational capabilities (Zahra and George, 2002). It combines prior knowledge and understanding (i.e. potential absorptive capacity) with processes of internalizing or transforming and implementing knowledge (i.e. realized absorptive capacity). It is the knowledge transformation component that 
encourages learning. Hence, high potential absorptive capacity or knowledge flow per se does not imply enhanced learning.

In our comparison of an international and a transnational MNE, we highlight the accentuated importance of subsidiary initiative where structural properties do not provide the rich communication linkages, work interdependencies, and formal and informal systems to manage learning. We note that actors i) have the ability to act in a purposeful and meaningful way in learning processes, i.e. they are intentional individuals (Elkjaer, 1999), and ii) higher-level learning processes are embedded in social practice as implicated by MNE structures other than the transnational model.

\section{Methodology}

The research was based on a case study of an international and a transnational MNE operating in the chemical industry and headquartered in Germany and the UK. It aimed to investigate the processes whereby artefacts were enacted by actors within a given MNE structure to generate a particular pattern of organizational learning. The study was systematic in deriving common analytical dimensions and in matching as many parameters at the home country level as possible for comparability of cases. In other words, a systematic comparison was performed in both MNE selection and analysis. Once access was gained to the parent companies and the nature of the relationship with each subsidiary was elicited in initial interviews, subsidiaries were selected on the basis of their network membership within the given MNE. This reflected either the integrated network or the international typology. An integrated network or a transnational form was identified along the dimensions of i) the extent to which capabilities and decisionmaking were decentralized, and ii) high interdependency of work existed between the subsidiaries and headquarters (see Bartlett and Ghoshal, 1989; Harzing, 1999). As all 
subsidiary operations were not of significant volume, a direct comparison of learning patterns across developing and developed countries was not possible. The two significant manufacturing operations of the British MNE-German and Polish—were compared with the Turkish and Italian subsidiaries of the German MNE. The British MNE had a marketing operation in Turkey, and a negligible manufacturing operation in Italy.

The selection of the industry of study was significant from the standpoint of high internationalization and innovativeness (see CEFIC, 2001). Thus, it lent itself to investigating cross-national incidents of learning. Although there was variation in the types of products manufactured, both the British and the German MNE operated a flowproduction process.

The field study employed 35 open-ended and semi-structured interviews (see Table 1 for a breakdown) conducted between March 2002 and May 2003 with executives overlooking international operations in marketing, manufacturing, HR and R\&D at parent companies and their counterparts at subsidiaries, as well as factory tours and document analyses.

Insert Table 1 about here

Respondents were requested to provide information on the types of practices that were transferred, resources that were made available by the parent company, the role of the parent company in subsidiary's operations, the procedures that were adopted by parent company for participation by the subsidiary team in the development and launch of an innovative product, and the way the product was modified to meet the preferences of a given host market. All interviews were taped and transcribed. The research 
examined actors' orientations to marketing and product-related knowledge such as formulations acquired from parent companies.

The direction of knowledge flow was measured as one-way where knowledge was transferred from the parent company to the subsidiary alone. For instance, where subsidiary interviewees mentioned the exporting of product-related information alone (which was cross-checked against respondents at the headquarters), this was coded as one-way knowledge flow. The transfer of knowledge between the parent and subsidiary in both directions constituted two-way flow of knowledge. This took the form of exporting and importing of product concepts and formulations by the headquarters. Learning was measured as 'higher-level' where subsidiaries displayed new patterns of thinking about business objectives, that is actors' efforts were directed at projection. Such learning took the form of proactive orientation to change based upon the anticipation of future needs (Sadler-Smith et al., 2001). An example of higher-level learning is the introduction of a new product idea to increase market share or to fight local competition. 'Lower-level' learning was measured by an actor's orientation that took the form of iteration or application of transferred artefacts. Based on Sadler-Smith et al.'s conceptualization, such a level of learning indicates a passive orientation to change. An example of lower-level learning is the adaptation of raw materials in product formulations that do not have behavioural implications.

Cases were systematically analyzed by initially outlining the main conditions to a given outcome within each particular case. This was followed by a comparison across cases using Mill's (1974) rigorous method to allow for theoretical generalization. This method offers control in case comparison and enables a holistic case-oriented approach to data analysis for more comprehensive explanations. It is suitable for configurational theory as that offered by comparative institutionalism since it explicitly conceptualises 
cases as combinations of attributes. In other words, it does not disaggregate cases into independent, analytically separate aspects, but, instead, treats configurations as different types of cases. It is based on the Boolean algebra that allows for an assessment of how different causes combine to affect relevant outcomes.

An instance of a phenomenon's occurrence was compared with an instance of its non-occurrence to identify 'bundles of conditions' that explained for the variation in outcome. The analysis required the elimination or the 'successive exclusion of the various circumstances which are found to accompany a phenomenon in a given instance, in order to ascertain what are those among them which can be absent consistently with the existence of the phenomenon’ (ibid., p. 392). It combined detailed case studies with systematic comparison. Through the method of difference or negative comparison, several cases characterized by dissimilar outcomes could be compared. Such an analysis contributed to the homogenization of construct definitions and measures to build mid-range theory ${ }^{2}$ (Eisenhardt, 1989).

\subsection{Research sites}

3.1.1 German MNE and its subsidiaries: German Chem was an internationally operating chemical company in Germany that was manufacturing-active in 52 countries. The unit on which this study was based produced cleansing agents for domestic use. During the last 10 years, German Chem grew, to a large extent, through acquisitions particularly in Europe. It left many key assets, such as R\&D, decentralized in its subsidiaries. However, as profitability fell below that of its two major rivals, the MNE decided to adopt a mix of transnational (among Western European (WE) sites) and a global strategy (among Central Eastern European (CEE) sites) to operating outside the domestic market in 1995 (strategic planning director, German Chem). The WE operations benefitted from interdependent relations and specialised operations. 
Whereas, CEE operations were managed centrally by Austria, i.e. the CEE HQ, and were not involved in new product development.

German Chem started its operation in Turkey through a licensing agreement in 1956, later to form a joint venture in 1963. As the foreign affiliate gained manufacturing experience and established credibility as a competent and reliable adaptor, it came under the full ownership of German Chem (in 1994). Thereafter, it was assigned more complex tasks such as developing products for local and regional markets.

One of the three significant R\&D facilities of German Chem outside of Germany was the MNE's Italian operation. The subsidiary was established as a greenfield investment in 1935. It was a member of the German Chem World (France, Benelux, Spain, Italy and Germany) that collectively generated about 70 per cent of the MNE's net sales (product manager at German Chem’s Italian subsidiary).

\subsubsection{British MNE and its subsidiaries: British Chem was a major chemical company} in the UK whose activities span over 50 countries. The unit on which this study was based was decorative paints, which was of strategic focus in the company. In the late 1990s, the company came under great pressure to achieve the maximum leverage out of a single project, hence it adopted an international approach to operating overseas in 1997. Underlying this change had been the emphasis on structuration and formalization, particularly in product development. With the closures of laboratories, subsidiaries grew dependent on the UK headquarters for new product ideas (General Manager, R\&D Europe): 'We are much better organized in terms of having country managers and functional structures, which are much more European-based. So in terms of R\&D, although we have some labs such as that in France and in Poland, our activities are all pretty well managed in terms of knowing what is going on and who is doing what... 
There are [links], whether they are solid or not, I would not like to say, some are solid some are dotted lines, but there is a lot of clarity'.

British Chem started its operation in Germany through its acquisition of British PLC (a pseudonym) in 1998. 'The British PLC culture [was] very much driven for cash, milking the business as hard as you can, do not drop a penny... British Chem in that respect is more generous. They give you time to develop' (managing director at British Chem's German subsidiary). There was no British Chem investment in the first two years of the acquisition. However, in 2001, part of the UK volume was transferred to the German site with the closure of one of the UK manufacturing facilities. This marked the efforts of the site to deliver the best in manufacturing performance.

The Polish site was acquired by British Chem in 1996. Culminated in the process was a change in management, emphasis on continuous improvement and the introduction of safety, health and environment (SHE) principles. British Chem maintained a small R\&D department in Poland for the local adaptation of its formulas. ${ }^{3}$

\section{Findings}

The case study findings show that there is variation in learning patterns at subsidiaries that are affiliated with either the international or the transnational MNE. However, this variation does not, in full, cohere with the distinction drawn by Bartlett and Ghoshal (1989). As expected, the German MNE’s transnational approach to creating and sharing knowledge in Western Europe through informal networks encourages two-way flow of knowledge and orientation from actors in the form of projection, i.e. higher-level learning. What is more interesting to note is that British Chem's international structure also provides room for higher-level learning, despite the absence of an informal network, owing to its Polish operation's orientation to project. 


\subsection{Learning within a transnational structure}

German Chem gradually began shifting its structure from multidomestic to one based on dispersed assets, specialized operations and interdependent relations, i.e. the transnational, among its WE operations in 1995. Local R\&D operations were integrated into the headquarters for global efficiency, responsiveness, and innovation. In the context of this shift, the MNE offers cultural training that is focused entirely on tearing down national borders. The international management training programmes help instil corporate values in German Chem's subsidiaries. 'You invest in a lot of infrastructure, not only machinery and equipment, but you build up very much in people, education, training' (corporate VP manufacturing at German Chem). 'We are sending people to Germany in the form of job rotation...It may be a short period for training purposes and visits for exchange of experience between headquarters and local units’ (R\&D manager at German Chem’s Italian subsidiary). Interdependency among subsidiaries is forged through Euro teams responsible for new product development. 'Now marketing units operate in Euro teams [which consist of a strategic business unit member from the headquarters and marketing managers across Europe]. The Euro team notion is quite important, because everybody is both a local manager and a member of a Strategic Business Unit team of that function' (VP market research/business intelligence at German Chem).

German Chem sustains transnational linkages among its long-established Western European subsidiaries. The Turkish subsidiary is an exception to this sample of participants. The participation of the Turkish site in the strong, tightly-knit network of Euro-team meetings encourages two-way flow of knowledge on product ideas between the German headquarters and the subsidiary. Although manufacturing excellence 
techniques are not transferred to the Turkish site, there is the introduction of HQdeveloped product recipes for local adaptation.

We [Turkish subsidiary] benefit from German Chem’s marketing strategies, guidelines and principles. These are clearly defined by the mother company...There is an emphasis on a common platform in the case of international brands. However, there is also room to modify the marketing mix in circumstances such as an economic crisis. We were allowed to adopt a volume strategy and reduce the price on a premium product during the crisis [in 2001]...We also have the flexibility to modify product formulations including those of international brands. (product manager at German Chem's Turkish subsidiary)

Crisis management in Turkey means that routines guided by procedures established in advance based on past experience need to be redefined to cope with the constant flux of change. The Turkish site is encouraged to search for solutions of its own to succeed in a chaotic environment. It also initiates change of a strategic nature to respond to external threats. 'In some cases, we develop our own formulations by increasing the active ingredients in products to match those of the competitors in the Turkish market' (product manager at German Chem's Turkish subsidiary). Members of the R\&D department are seconded to German headquarters to work on product formulations that are more cost effective or yield higher performance. 'I was in Germany for 12 months last year to lead a project on re-formulating high-foam washing powder for hand wash. The aim was to outline the technical and financial advantages and disadvantages of using the re-formulated product for the European users. We came to the decision that the European formulation did not introduce cost advantages or higher performance at the same cost level' (product development engineer at German Chem's Turkish 
subsidiary). The Turkish subsidiary also changed the product formulation of the purple variant of German Chem's most successful softener in Europe that was adopted by the transnational's other European operations. These exemplify the active orientation that the subsidiary assumes in directing its efforts to the future needs of the organization (i.e. projection), which indicates higher-level learning.

The learning outcome at German Chem's Italian operation is similar to that found at the Turkish site. 'We have the opportunity to participate directly in the work of German Chem Group, developing new ideas directly. While in the past, it was difficult, because there was not so much freedom to develop ideas directly in Italy, France or Spain...In some cases, they [headquarters] have an original formula, for example the de-greaser [all-purpose cleaner]' (R\&D manager at German Chem’s Italian subsidiary). The subsidiary is able to launch not only marketing changes, such as those in perfumes and colours, but also technical changes as those in the viscosity levels of products.

We worked 10 years ago to re-launch formula with a new raw material. The reason was the bio-degradability of the old raw material. So an international team was established. We were part of this team. First studies were done in Germany. We then worked to adapt the process in Italy, France and Spain...High viscosity was very important for Italy, but not so important for other countries. So we had to find a way to increase the viscosity of the product having the same level of cost as in other countries. We followed a very precise process with specific parameters. The results were then sent to Germany. (R\&D manager at German Chem’s Italian subsidiary)

Strong test results convinced the German headquarters to launch the product. By the same token, the subsidiary proactively took the decision to introduce a marsiglia- 
based variant in international brands, in particularly softeners, to fight competition. This has been strongly opposed by the parent company.

It is a huge trend for Italy. Marsiglia is a soap bar, which was used in the past, in the $20^{\text {th }}$ century, a soap used by my grandmother. It has a very characteristic odour. It is quite well known for being quite effective...It is cheap and environmentally friendly...About four to five years ago, we saw a trend in the detergents [among local producers] that were using this marsiglia soap as a marketing concept. It was an enormous success...We were the first to introduce it into dishwashing, then into softeners. Can you imagine into the softeners? It took us three to four years to convince Germany in this case that marsiglia was an interesting trend. (product manager at German Chem’s Italian subsidiary)

The German headquarters did not want to adopt marsiglia, because they regarded it as a cheap, ineffective, bad-smelling product that would damage the image of their premium-branded goods. 'In the beginning, the test results were not enough to sell to the top management that it was a good process, but then they realized that it was possible' (product manager at German Chem's Italian subsidiary). Such experimentation and risk-taking at the subsidiary indicates an orientation towards projection. The subsidiary initiates changes of a strategic nature to fight competition. Such experimentation also enables headquarters to benefit from local experiences. This is illustrated by the Italian subsidiary's local experience in physical behaviour of particle sizes in dispersion and shared stress: 'We have this kind of experience and facility here, thus had more possibility than colleagues in Germany [HQ] or in Spain and France to perform trials. We also have experience in [Y brand] softener, because Lomazzo was one of the first plants to produce softeners in the [German Chem] Group’ (R\&D manager at German Chem's Italian subsidiary). This suggests a two-way flow of 
knowledge on product ideas and formulations between the Italian subsidiary and the parent company.

\subsection{Learning within an International structure}

Although British Chem perceives itself to be locally responsive to market differences in terms of packaging and colour range, it predominantly exports product ideas and recipes to its European subsidiaries. In line with Bartlett and Ghoshal's international model, knowledge is developed at the centre and exported to overseas units (strategic research manager, British Chem). Subsidiaries are responsible for minor changes to the product. 'For local development of products, usually that is best done very close to the customer in a local country, you know, you are putting few extra colours on to the colour range or just making a small change to a particular product... We do have a discipline, a template, an operating framework that says what is decided where, which decisions are to be taken locally, regionally, internationally and what things you need to tell people' (research and innovation director, British Chem). The rules, procedures and policies for new product development are standardized and formalized.

British Chem supports the development of its German subsidiary's innovative capability by transferring the technology needed to adapt product formulations developed at headquarters to local raw materials. However, despite the shift from a multidomestic to an international structure in 1997, there is not an emphasis on expatriate management or international training to acculturate subsidiary members at British Chem. There is one-way flow of knowledge through exporting of product ideas and improvements in manufacturing accuracy.

With the [X brand], what we did is that we exported it from the UK. So they [the

German subsidiary] took the same range as the UK, and then gradually over a period of time, we formulated a match using their raw materials...They sorted their 
factory out in terms of their quality. So they are now making it for themselves as well as for Czech and Hungary. (general manager R\&D Europe, British Chem)

However, the $[\mathrm{X}]$ brand that was adapted with alacrity by the Polish site was resisted by the German site. 'Four years ago, when I discussed this with Germany and the UK, they [Germany] asked "why do you want to launch this when other paints cover well, better than those of the competitors?”' (marketing director at the Polish subsidiary of British Chem). The German subsidiary's conservative attitude to leveraging parent company competences is related to the path-dependent behaviour established prior to its acquisition. It assumes a reactive orientation to improving its processes in continuous steps to meet headquarters standards.

Because people used to be independent for 40 years in their history, and all of a sudden there comes a parent company, puts a foot on us and says 'we will guide you through some of our standards. We have got company standards that you have to follow'. People see that sometimes as pain. (managing director at British Chem’s German subsidiary)

The German subsidiary adheres to old ways of working rather than engaging in strategic reorientation. Its reliance on the past (i.e. iteration) and pragmatic adaptation of products to the German market (i.e. application), indicate lower-level learning.

There is also one-way flow of knowledge such as product recipes from British Chem to the Polish subsidiary. 'All the recipes are owned, in fact, by the UK. So if we want to make changes to the recipes, those need to be approved by the UK. There are people from the UK labs who come here and advise' (marketing director at British Chem's Polish subsidiary). This is related to time and resource constraints such as the size of the R\&D department at the Polish site (head of research lab at British Chem's Polish subsidiary). If the Polish site has an idea for a new product, it has the autonomy 
to prepare its own recipe, discuss its test results with the parent company, and sell the product under the international brand name. The subsidiary also 'co-operat[es] in some projects concerning the future of solvent-borne products in Poland. We are also discussing NPD [new product development] regularly’ (R\&D manager at British Chem's Polish subsidiary). Although the subsidiary is perceived as the least technologically advanced of all players in Poland, and 'have probably the smallest and not probably the best equipped R\&D lab..., we could implement this [low-volume, highly profitable, value-added brands] during the preliminary phase of the launch on the market even without having all the stuff [technical capabilities] locally' (marketing director at the Polish subsidiary of British Chem). Thus, there is room for experimentation at the Polish site. This is also reflected by its ready acceptance of new ideas from the parent company. 'They [the Polish subsidiary] are hungry for ideas. This is not to say they do not have good ideas of their own, but they are hungry' (general manager R\&D Europe, British Chem). The Polish site displays an orientation based upon an anticipation of future market needs (i.e. projection).

In terms of the sophistication in the Polish market now...there was no really major paint company there, the paint companies have gone in and started to grow the market from a value point of view, getting them into colour, bringing innovation into the marketplace...As a market, it has proved really responsive to the innovation... They are responding much more readily than say the Germans did, who have perhaps been stuck in their way. (general manager R\&D Europe, British Chem)

Although one might expect the structural properties of British Chem's coordination efforts to be associated with the iteration of past practices or application of practices to current circumstances at the site, there is an effort to project towards the future and to 
establish new patterns of thinking about business objectives. This suggests higher-level learning. As is illustrated below, the company revised designs and manufacturing processes to lead the industry trend, actively engaging in change of a strategic kind.

About four years ago, we were looking at different products to launch which would be innovative, different and better than what the competition has got. There were no products...the market at that point in time seemed to be following the way of developing the tinting business...Looking at the UK market, there were suggestions that launching colours would not be a bad idea, because it works in the UK. However, we are afraid of advices of doing something because it works in the UK. So we did not really know which would be the preferred route. (marketing director at the Polish subsidiary of British Chem)

The Polish site felt confident to launch colours when it observed the market performance of another imported product indicating high value to consumers. It was able to recast its strategy and values sufficiently radically to raise its market position to second in rank.

\section{Discussion and Conclusions}

The findings indicate that higher-level learning is encouraged where a multinational operates an interorganizational network of interdependent units with emphasis on indirect and personal control through strong corporate culture (see Table 2 for an overview of the patterns of learning at subsidiaries). This concurs with Bartlett and Ghoshal's assertion that the transnational structure is an effective means of organizing from a learning perspective. It highlights the tacit components of capabilities that are embedded in a firm's social context, making them more unique, less imitable and thus better able to create strategic value. Attempts to integrate subsidiaries strategically 
provide the means to interact and exchange knowledge (Inkpen and Dinur, 1998). For instance, personnel transfers help organizational members understand the business, which in turn makes knowledge more fluid and easier to put into practice (Nonaka, 1994).

\section{Insert Table 2 about here}

More importantly, the findings point to the significance of agency, or adaptation to contexts that require either idiosyncratic or ongoing changes, where structural properties of a multinational are not conducive to higher levels of learning. The attention is drawn here to the orientations of multiple actors as they intentionally or unintentionally change their recognizable pattern of interdependent actions away from the resource and capability implications of a transnational structure. As demonstrated by the cases, MNEs' efforts to transfer 'abstract knowledge' as that related to products are linked to subsidiaries' efforts to iterate, apply or project these practices to guide behaviour. For example, British Chem's Polish subsidiary changes product formulations from HQ and sets an industry trend despite the absence of coordination capabilities or liaison mechanisms at its disposal. This highlights a process of learning that is affected by endogenously-induced change, i.e. human action displayed by the adaptation of rules to new circumstances (cf. Becker et al., 2005).

The characteristics of a transnational model among WE operations can be observed in the German MNE's heavy emphasis on developing horizontal linkages and subsidiary capabilities, as well as exercising indirect personal form of control across these operations. The Euro-team meetings, which serve as integrating mechanisms between various research teams (cf. Zander and Sölvell, 2000), socialize local managers 
into the corporate culture and create a network for the cross-fertilization of ideas between subsidiaries and HQ. German Chem emphasizes the acculturation of its subsidiaries through international transfers of managers and international training (i.e. indirect personal control, Harzing, 1999). The emphasis on expatriate management is evident in German Chem's number of HQ personnel assigned to various subsidiaries. There is a German Chem member working in the marketing department of the Italian subsidiary, and there are two German expatriates, one of whom is in a general manager role and the other in an engineering role at the Turkish subsidiary. In comparison, despite their recent acquisition, British Chem neither has HQ personnel serving its German and Polish subsidiaries, nor provides technical international training to its subsidiary members. Rather, it chooses to standardize and formalize rules, procedures and policies to co-ordinate and control activities. Berthoin-Antal et al. (2001) highlight the importance of networking in every type of organisational structure for organisational learning. The absence of such mechanisms explains why British Chem's international structure did not necessarily encourage higher-level learning at its subsidiaries. As the mode-of-entry into Germany and Poland indicates, British Chem has chosen to limit commitment to and mutual dependence on subsidiaries through acquisitions. This explains, in part, why the German subsidiary tends to resist product ideas from British Chem. The unit's rich administrative heritage has a role to play in its passive orientation to new ideas. However, British Chem’s Polish subsidiary displays entrepreneurship in developing knowledge. Although an international structure would suggest that the greater dependence of subsidiaries on the centre for the diffusion of knowledge does not endow firms with much autonomy to develop knowledge, there is strategic reorientation at the Polish operation to generate knowledge towards future aspirations. This is elicited with a focus on a unit of analysis that captures a level of granularity significant for 
learning, i.e. actors' orientations to putting acquired knowledge into practice (HowardGrenville, 2005). In spite of the relatively centralized means of controlling product development-pressure that is felt by both the German and the Polish subsidiary-, there is flexibility at the Polish subsidiary within which practices can 'evolve' without headquarters' involvement. Unlike what is commonly perceived as significant, the Polish site has neither relied on a shared research community nor invested heavily in R\&D to exhibit higher-level learning (e.g. Lane and Lubatkin, 1998). What underlies the level of learning at the Polish site is its receptivity to learn (see Inkpen, 1997). It assumes an active role in searching for and adapting new product ideas to introduce to the market. This highlights the importance of a subsidiary's motivational disposition to seek knowledge (Szulanski, 1996; Gupta and Govindarajan, 2000), and put it into practice. For instance, the risk taken by the subsidiary in launching colours in a market where the future was perceived to be in the tinting business shows its orientation to 'project'. By contrast, the German subsidiary responded to product ideas and recipes through ‘iteration and application’ that was characterized by caution, inhibition, and an aversion to risk-taking and experimentation. This aversion could not be compensated by the structural properties of an international structure for higher-level learning.

Although the focus here has been on how agency rather than structure shapes learning, it is crucial for us to also highlight the institutional influences on learning. The British and the German MNEs display some of the characteristics of a compartmentalised and a collaborative national business system (NBS) (Whitley, 1999, 2007). For instance, the British MNE chooses to exercise control through standardisation and formalisation of rules and procedures rather than through expatriate management or international training. This is consistent with the characteristics of a compartmentalised NBS where managers adopt a financial conception of managerial 
control (Aguilera and Jackson, 2003). Unlike the British MNE, the German MNE emphasises social integration mechanisms to break institutional logics at its Western European subsidiaries. It acculturates its subsidiaries through international transfers of managers and international training. This is consistent with the characteristic of a collaborative NBS where managers adopt a functional conception of managerial control (ibid.). It is also in line with the long-termist approach to development that is complemented by a highly developed system of vocational education and training in Germany (Ferner et al., 2001). In the absence of a broader sample of positive and negative cases, it is difficult to discern the direct impact of home institutional context on subsidiary learning. The direct effect of MNE structure can be more easily observed. For instance, in the Italian case, the German MNE coordinated operations by emphasising cross-functional teamwork, training, and visits for exchange of experience between HQ and the local unit. The multiple linkages granted by the transnational structure enhanced the subsidiary’s ability to influence key HQ decisions particularly in product specifications and design.

An important point that appears to have been overlooked in MNE research is that capabilities of subsidiaries can be a source of change that leads to entrepreneurship. This rests on the ontology that routines embody a duality of structure and agency (Feldman and Pentland, 2003), not simply structures. The learning implications of Bartlett and Ghoshal's MNE structures are fine-tuned with the conceptualization of learning as practice (Brown and Duguid, 1991; Lave, 1993) where absorptive capacity is perceived to combine both prior knowledge (potential capacity) and transformative dimension (realized capacity). Subsidiary initiative, as the Polish subsidiary of British Chem highlights, is not necessarily contingent on horizontal linkages and interdependencies in the corporate context, as found at German Chem. By contrast to 
what is posited in terms of the negative implications of the functional structure on a firm's absorptive capacity, the Polish subsidiary is not discouraged from discrete proactive undertaking (e.g. Van den Bosch et al., 1999).

The findings have implications for parent company and subsidiary managers. They point to the importance of actors' orientation to transferred knowledge beyond what a network structure offers. They suggest that subsidiary learning can also be fostered in the absence of subsidiary integration mechanisms if subsidiaries have the motivational disposition to take on board new ideas.

This study also has implications for organizational learning in international settings, which has commonly been equated with knowledge transfer (e.g. Zahra et al., 2000; Vermeulen and Barkema, 2001). To conceptualize learning as knowledge transfer severely limits the role of human agency. In order to conceptualize learning in 'agentic terms', we need to highlight actors' recognition, location, and implementation of knowledge as a dynamic process in their ongoing and situated transactions. By adopting an agency-based understanding of learning, we reconcile the two aspects of learning, i.e. knowledge transfer and the actor's orientation to acquired knowledge for a more refined understanding of the concept within the MNE context.

\section{Notes}

1. Fiol and Lyles' conceptualisation of learning is similar to Argyris and Schön's (1978) idea that there is i) deviation-reducing adaptation that occurs when there is understanding within a given framework reflecting single-loop learning, and ii) deviation-amplifying adaptation that involves the creation of new causal relationships built on a new base of assumptions reflecting double-loop learning. This distinction is adapted here to routine-based account of organisational learning as reinforcement or transformation of routines, for Argyris and Schön's definition 
refers to individual learning in organisations (see Crossan et al., 1995; Prange, 1999; Lähteenmäki et al., 2001).

2. Mid-range theory is one that is 'testable, novel, and empirically valid, but lack[s] the sweep of theories like resource dependence, population ecology, and transaction cost' (Eisenhardt, 1989: 547).

3. Although the Polish site is not technologically advanced, it has the right people skills to develop and manufacture high-quality products. 'We are much more effective than the UK plant for export markets. That is also the reason why they are taking the product from us. They would not be able to launch those products in Hungary, in Czech successfully if they were to take it from the UK' (marketing director at the Polish subsidiary of British Chem). 


\section{References}

Aguilera, R. V. and Jackson, G. (2003). "The Cross-National Diversity of Corporate Governance: Dimensions and Determinants”, Academy of Management Review, Vol. 28, pp. 447-65.

Argyris, C. and Schön, D. (1978). Organizational Learning: A Theory of Action Perspective, Addison-Wesley Publishing, Reading.

Bartlett, C. A. and Ghoshal, S. (1989), Managing Across Borders: The Transnational Solution, Harvard Business School Press, Boston.

Becker, M. C., Lazaric, N., Nelson, R. R. and Winter, S. G. (2005), "Applying Organizational Routines in Understanding Organizational Change”, Industrial and Corporate Change, Vol. 14, pp. 775-91.

Berthoin-Antal, A., Lenhardt, U., and Rosenbrock, R. (2001). "Barriers to Organizational Learning”, in M Dierkes, A. Berthoin Antal, J. Child, and I. Nonaka (Eds), Handbook of Organizational Learning and Knowledge, Oxford University Press, Oxford, pp. 865-885.

Birkinshaw, J. M. and Hood, N. (1998), "Multinational Subsidiary Development: Capability Evolution and Charter Change in Foreign-owned Subsidiary Companies”, Academy of Management Review, Vol. 23, pp. 773-95.

Brown, J. S. and Duguid, P. (1991). “Organizational Learning and Communities-ofpractice: Toward a Unified View of Working, Learning, and Innovating”, Organization Science, Vol. 2, pp. 40-57.

CEFIC (2001). Facts and Figures: The European Chemical Industry in a Worldwide Perspective, Brussels, The European Chemical Industry Council, www.cefic.org.

Cohen, W. M. and Levinthal, D. A. (1990). “Absorptive Capacity: A New Perspective on Learning and Innovation”, Administrative Science Quarterly, Vol. 35, pp. 12852.

Crossan, M. M., Lane, H. W., White, R. E. and Djurfeldt, L. (1995). "Organizational learning: Dimensions for a theory”, The International Journal of Organizational Analysis, Vol 3, pp. 337-60.

Dodgson, M. (1993), “Organizational Learning: A Review of Some Literatures", Organization Studies, Vol. 14, pp. 375-94.

Easterby-Smith, M., Burgoyne, J. and Araujo, L. (1999). Organizational Learning and the Learning Organization: Developments in Theory and Practice, Sage Publications, London.

Eisenhardt, K. M. (1989), "Building Theories from Case Study Research”, Academy of Management Review, Vol. 14, pp. 532-50.

Elkjaer, B. (1999). "In Search of Social Learning Theory', in Easterby-Smith, M., Burgoyne, J. and Araujo, L. (Eds), Organizational Learning and the Learning Organization, Sage Publications, London, pp. 75-91.

Emirbayer, M. and Mische, A. (1998), „What is Agency?”, American Journal of Sociology, Vol. 103, pp. 962-1023.

Feldman, M. S. and Pentland, B. T. (2003), "Reconceptualizing Organizational Routines as a Source of Flexibility and Change”, Administrative Science Quarterly, Vol. 48, pp. 94-118.

Ferner, A., Quintanilla, J. and M. Z. Varul (2001). "Country-of-origin effects, hostcountry effects, and the management of HR in multinationals: German companies in Britain and Spain”, Journal of World Business, Vol. 36, pp. 107-28.

Fiol, C. M. and Lyles, M. A. (1985), “Organizational Learning”, Academy of Management Review, Vol. 10, pp. 803-13. 
Gupta, A. K. and Govindarajan, V. (2000), “Knowledge Flows within Multinational Corporations”, Strategic Management Journal, Vol. 21, pp. 473-96.

Harzing, A.-W. K. (1999), Managing the Multinationals: An International Study of Control Mechanisms, Edward Elgar, Cheltenham.

Hedlund, G. (1994), "A Model of Knowledge Management and the $\mathrm{N}$-form Corporation”, Strategic Management Journal, Vol. 15, pp. 73-90.

Hendry, C., Arthur, M. B. and Jones, A. M. (1995), Strategy through People: Adaptation and Learning in the Small-Medium Enterprise, Routledge, London.

Howard-Grenville, J. A. (2005), “The Persistence of Flexible Organizational Routines: The Role of Agency and Organizational Context”, Organization Science, Vol. 16, pp. 618-36.

Inkpen, A. C. (1997), “An examination of knowledge management in international joint ventures”, in Cooperative Strategies: North American Perspectives, Beamish, P. W. and Killing, J. P. (Eds), New Lexington Press, San Francisco, pp. 337-69.

Inkpen, A. C. and Dinur, A. (1998), "Knowledge management processes and international joint ventures”, Organization Science, Vol. 9, pp. 454-68.

Kedia, B. L. and Bhagat, R. S. (1988), "Cultural constraints on transfer of technology across nations: Implications for research in international and comparative management”, Academy of Management Review, Vol. 13, pp. 559-71.

Lähteenmäki, S., Toivonen, J. and Mattila, M. (2001). "Critical Aspects of Organizational Learning Research and Proposals for its Measurement", British Journal of Management, Vol. 12, pp. 113-29.

Lane, P. J. and Lubatkin, M. (1998), "Relative absorptive capacity and interorganizational learning”, Strategic Management Journal, Vol. 19, pp. 461-77.

Lave, J. (1993). "The Practice of Learning”, in S. Chaiklin and J. Lave (Eds), Understanding Practice: Perspectives on Activity and Context, Cambridge University Press, Cambridge, pp. 3-34.

Levitt, B. and March, J. G. (1988), “Organizational Learning”, Annual Review of Sociology, Vol. 14, pp. 319-40.

Macharzina, K., Oesterle, M.-J. and Brodel, D. (2001). 'Learning in multinationals', in Dierkes, M., Berthoin Antal, A., Child, J. and Nonaka, I. (Eds), Handbook of Organizational Learning and Knowledge, Oxford, Oxford University Press, pp. 631-56.

Mill, J. S. (1974), A System of Logic Ratiocinative and Inductive: Being a Connected View of the Principles of Evidence and the Methods of Scientific Investigation, University of Toronto Press, Toronto.

Miller, D., Lant, T. K., Milliken, F. J. and Korn, H. J. (1996), "The Evolution of Strategic Simplicity: Exploring Two Models of Organizational Adaptation”, Journal of Management, Vol. 22, pp. 863-87.

Nelson, R. R. and Winter, S. G. (1982), An Evolutionary Theory of Organizational Change, Belknap, Cambridge.

Nonaka, I. (1994), “A dynamic theory of organizational knowledge creation", Organization Science, Vol. 5, pp. 14-37.

Prahalad, C. K. and Doz, Y. L. (1981), “An Approach to Strategic Control in MNEs”, Sloan Management Review, Summer, pp. 5-13.

Prange, C. (1999). “Organizational Learning-Desperately Seeking Theory?”, in M. Easterby-Smith, J. Burgoyne \& L. Araujo (Eds), Organizational learning and the Learning Organization, Sage Publications, London, pp. 23-43.

Sadler-Smith, E., Spicer, D. P. and Chaston, I. (2001), "Learning Orientations and Growth in Smaller Firms”, Long Range Planning, Vol. 34, pp. 139-58. 
Szulanski, G. (1996), "Exploring Internal Stickiness: Impediments to the Transfer of Best Practice within the Firm”, Strategic Management Journal, Vol. 17, pp. 2744.

Uhlenbruck, K., Meyer, K. E. and Hitt , M. A. (2003). “Organizational Transformation in Transition Economies: Resource-based and Organizational learning perspectives”, Journal of Management Studies, Vol. 40, pp. 257-82.

Van den Bosch, F. A. J., Volberda, H. W. and Boer, M. de (1999), "Co-evolution of firm absorptive capacity and knowledge environment: Organizational forms and combinative capabilities”, Organization Science, Vol. 10, pp. 551-68.

Vermeulen, F. and Barkema, H. (2001), "Learning through Acquisitions", Academy of Management Journal, Vol. 44, pp. 457-76.

Whitley, R. (1999). Divergent Capitalisms: The Social Structuring and Change of Business Systems, Oxford University Press, Oxford.

Whitley, R. (2007). Business Systems and Organizational Capabilities: The Institutional Structuring of Competitive Competences, Oxford University Press, Oxford.

Zahra, S. A. and George, G. (2002), "Absorptive capacity: A review, reconceptualization, and extension”, Academy of Management Review, Vol. 27, pp. 185-203.

Zahra, S. A., Ireland, R. D. and Hitt, M. A. (2000), "International Expansion by New Venture Firms: International Diversity, Mode of Market Entry, Technological Learning, and Performance”, Academy of Management Journal, Vol. 43, pp. 92550.

Zander, I.and Sölvell, Ö. (2000), "Cross-border Innovation in the Multinational Corporation: A Research Agenda”, International Studies of Management and Organization, Vol. 30, pp. 44-67. 
Table 1. Case study Firms

\begin{tabular}{|l|l|l|l|l|l|l|}
\hline Firms & \multicolumn{6}{|c|}{ Number of Respondents } \\
\hline & HQ & $\begin{array}{l}\text { German } \\
\text { subsidiary }\end{array}$ & $\begin{array}{l}\text { Polish } \\
\text { subsidiary }\end{array}$ & $\begin{array}{l}\text { Italian } \\
\text { subsidiary }\end{array}$ & $\begin{array}{l}\text { Turkish } \\
\text { subsidiary }\end{array}$ & Total \\
\hline $\begin{array}{l}\text { British } \\
\text { Chem }\end{array}$ & 11 & 2 & 5 & N/A & N/A & 18 \\
\hline $\begin{array}{l}\text { German } \\
\text { Chem }\end{array}$ & 6 & N/A & 5 & 2 & 4 & 17 \\
\hline Total & 17 & 2 & 10 & 2 & 4 & 35 \\
\hline
\end{tabular}


Table 2. Patterns of Learning at Subsidiaries

\begin{tabular}{|c|c|c|c|c|}
\hline MNEs & \multicolumn{2}{|l|}{ British Chem } & \multicolumn{2}{|l|}{ German Chem } \\
\hline MNE structure & \multicolumn{2}{|l|}{ International } & \multicolumn{2}{|c|}{ Western European network: transnational } \\
\hline Knowledge transfer & \multicolumn{2}{|c|}{ Exports product ideas and recipes } & \multicolumn{2}{|c|}{ Exports and imports product concepts and formulations } \\
\hline Subsidiaries & Germany & Poland & Turkey & Italy \\
\hline $\begin{array}{l}\text { Mode of entry into host } \\
\text { country }\end{array}$ & Acquisition (1998) & Acquisition (1996) & $\begin{array}{l}\text { Licensing agreement in 1956, } \\
\text { joint venture in 1963, full } \\
\text { ownership in } 1994\end{array}$ & Greenfield (1935) \\
\hline Mode of control & \multicolumn{2}{|c|}{$\begin{array}{l}\text { Standardized and formalized new product development } \\
\text { procedures }\end{array}$} & \multicolumn{2}{|c|}{$\begin{array}{l}\text { Indirect, personal control: } \\
\text { Emphasis on strong ‘corporate culture', acculturating subsidiaries } \\
\text { through international management training and secondment }\end{array}$} \\
\hline $\begin{array}{l}\text { Level of learning } \\
\text { (Direction of } \\
\text { knowledge flow and } \\
\text { actor's orientation to } \\
\text { acquired knowledge) }\end{array}$ & $\begin{array}{l}\text { Lower-level } \\
\text { (One-way flow of } \\
\text { knowledge, Iterate and } \\
\text { apply) }\end{array}$ & $\begin{array}{l}\text { Higher-level } \\
\text { (One-way flow of } \\
\text { knowledge, Project) }\end{array}$ & $\begin{array}{l}\text { Higher-level } \\
\text { (Two-way flow of knowledge, } \\
\text { Project) }\end{array}$ & $\begin{array}{l}\text { Higher-level } \\
\text { (Two-way flow of knowledge, } \\
\text { project) }\end{array}$ \\
\hline
\end{tabular}


